Article

\title{
Effect of Increasing the Dietary Protein Content of Breakfast on Subjective Appetite, Short-Term Food Intake and Diet-Induced Thermogenesis in Children
}

\author{
Nick Bellissimo ${ }^{1, *}$, Tammy Fansabedian ${ }^{1}$, Vincent C.H. Wong ${ }^{1}$, Julia O. Totosy de Zepetnek ${ }^{2} \mathbb{D}$, \\ Neil R. Brett ${ }^{1}$, Alexander Schwartz ${ }^{1}{ }^{\circledR}$, Stephanie Cassin ${ }^{3}{ }^{\circledR}$, Katherine Suitor ${ }^{1}$ \\ and Dérick Rousseau ${ }^{4}$ \\ 1 School of Nutrition, Ryerson University, Toronto, ON M5B-2K3, Canada; tfansabe@ryerson.ca (T.F.); \\ vincent.ch.w@gmail.com (V.C.H.W.); neil.brett@ryerson.ca (N.R.B.); \\ alexander.sasha.schwartz@gmail.com (A.S.); katherine.suitor@ryerson.ca (K.S.) \\ 2 Faculty of Kinesiology and Health Studies, University of Regina, Regina, SK S4S-0A2, Canada; \\ julia.totosy@uregina.ca \\ 3 Department of Psychology, Ryerson University, Toronto, ON M5B-2K3, Canada; stephanie.cassin@ryerson.ca \\ 4 Department of Chemistry \& Biology, Ryerson University, Toronto, ON M5B-2K3, Canada; \\ rousseau@ryerson.ca \\ * Correspondence: nick.bellissimo@ryerson.ca; Tel.: +14-16-979-5000-x553026
}

Received: 8 September 2020; Accepted: 30 September 2020; Published: 2 October 2020

\begin{abstract}
Dietary protein affects energy balance by decreasing food intake (FI) and increasing energy expenditure through diet-induced thermogenesis (DIT) in adults. Our objective was to investigate the effects of increasing the dietary protein in an isocaloric breakfast on subjective appetite, FI, blood glucose, and DIT in 9-14 y children. Two randomized repeated measures designs were used. In experiment 1, 17 children ( 9 boys, 8 girls) consumed isocaloric meals ( $450 \mathrm{kcal}$ ) on four separate mornings containing: $7 \mathrm{~g}$ (control), $15 \mathrm{~g}$ (low protein, LP), $30 \mathrm{~g}$ (medium protein, MP) or $45 \mathrm{~g}$ (high protein, HP) of protein. Blood glucose and subjective appetite were measured at baseline and regular intervals for $4 \mathrm{~h}$, and FI was measured at $4 \mathrm{~h}$. In experiment 2, 9 children ( 6 boys, 3 girls) consumed the control or HP breakfast on two separate mornings, and both DIT and subjective appetite were determined over $5 \mathrm{~h}$. In experiment 1 , all dietary protein treatments suppressed subjective appetite compared to control $(p<0.001)$, and the HP breakfast suppressed FI compared with the LP breakfast and control $(p<0.05)$. In experiment 2, DIT was higher after HP than control $(p<0.05)$. In conclusion, increasing the dietary protein content of breakfast had favorable effects on satiety, FI, and DIT in children.
\end{abstract}

Keywords: diet-induced thermogenesis; dietary protein; satiety; glycemic response

\section{Introduction}

The increasing proportion of children in Western countries categorized as overweight or obese has led to an interest in the role of a high protein diet to support healthy body weights [1]. Yet, there is a lack of effective dietary tools available for body weight maintenance in children, which highlights the need to identify potential preventative dietary strategies. It is well established that macronutrient composition plays a role in satiety and energy intake. A hierarchy exists where protein is the most satiating macronutrient compared to carbohydrates and fats, and has been shown to regulate energy intake in adults [2,3]. While the benefits of dietary protein intake on body weight maintenance and energy balance have been reported in both short- and long-term studies in adults, there is limited existing literature in children $[4,5]$. A recent study in participants aged 2-22 y reported that higher 
protein intakes in childhood were related to healthier body mass index (BMI) trajectories in young adulthood [6]. Similarly, a large, multicenter European study previously demonstrated that a small increase in protein intake combined with a small reduction in glycemic index can limit weight gain following weight loss among children aged 5-18 y [7]. In particular, previous research has associated eating breakfast with greater energy intake control and weight maintenance in children compared to breakfast skipping [8]. Therefore, examining the effects of breakfast composition, specifically protein content, on food intake and appetite regulation is essential in order to inform future nutrition recommendations for children.

Dietary protein intake may regulate energy balance by decreasing food intake (FI), increasing satiety hormones [3,9], improving glucose regulation $[10,11]$ and increasing energy expenditure through diet-induced thermogenesis (DIT) [12]. Diet-induced thermogenesis is estimated to account for approximately $10 \%$ of daily energy expenditure in humans and is comprised of the energetic costs of postprandial processes including food breakdown, enzyme synthesis, peristalsis, and nutrient uptake and assimilation [13]. A body of literature currently exists in adults suggesting protein is not only the most thermogenic macronutrient, but also the most satiating, suggesting a potential relationship between satiety and DIT [2]. While DIT is associated with subjective satiety in both healthy weight and overweight adults [12], this relationship is still relatively unexplored in children and adolescents. In adults, dietary protein increases DIT more than carbohydrates and fat [14-16] due to the high-energy costs associated with protein synthesis [17] and changes in substrate utilization that favors fat oxidation [18].

Previous work in adults has shown that $\sim 30 \mathrm{~g}$ of protein at a meal was needed to maximize satiety and suppress FI $[19,20]$. Some of these functional benefits have also been demonstrated in children, as we have demonstrated that $50 \mathrm{~g}$ of whey protein suppresses FI more than glucose [21]. In children [22] and adolescents [23,24], protein intakes of $\geq 30 \mathrm{~g}$ at mealtime have been shown to suppress FI compared to lower protein quantities. Protein metabolism and energy expenditure are dependent on the protein source as a function of amino acid oxidation and the high energy costs of excess protein metabolism [2]. Indeed, consuming an egg-based breakfast significantly reduced short-term energy intake in children [22]. Yet, most research has focused on dairy proteins $[18,25,26]$, and few studies have investigated potential mechanisms of short-term FI suppression and satiety following varying non-dairy protein consumption in children.

The present study investigated the effects of dietary protein included at breakfast on DIT and subjective appetite in 9-14 y children. Our objectives were two-fold: (1) To assess the effects of increasing the dietary protein portion of an isocaloric meal on subjective appetite, glycemic response, and short-term FI (experiment 1) and, (2) to determine the effect of a high protein meal on DIT in children (experiment 2). Based on our current understanding, we hypothesized that a breakfast meal higher in protein content would increase subjective satiety and DIT to a greater extent than a breakfast meal with lower protein content. Furthermore, a breakfast meal with higher protein content would demonstrate lower carbohydrate oxidation than a breakfast meal lower in protein.

\section{Materials and Methods}

\subsection{Participants}

Seventeen boys and girls 9-14 y were recruited for both experiments through advertisement postings on an online classifieds' website, school and community bulletin boards, and by word-of-mouth. Average baseline participant characteristics are described in Table 1 . Seventeen children $(n=9$ boys, $n=8$ girls) participated in experiment 1 , and a subset of ten individuals ( $n=7$ boys, $n=3$ girls) participated in experiment 2 . Respiratory and subjective appetite data for one participant were excluded in experiment 2 due to fidgeting during the measurement period and was not included in analyses. A sufficient estimated sample size was based on a single group mean from our previous work [27]. The Research Ethics Board at Ryerson University approved the study and the study was 
registered at clinicaltrials.gov (NCT02200796). Inclusion criteria were children who were habitual breakfast consumers and able to consume the assigned foods. Participants were excluded if they were dieting, taking any medications that would affect study outcomes, had food allergies or sensitivities to test foods, or had any significant learning or behavioral difficulties. While body composition may influence DIT in adults [28], it has consistently been shown that DIT is not different between obese and normal weight children following isocaloric test meals [29-31]. As such, our inclusion/exclusion criteria did not include body composition.

Table 1. Participant characteristics.

\begin{tabular}{ccc}
\hline Characteristic & Experiment $\mathbf{1}(\boldsymbol{n}=\mathbf{1 7})$ & Experiment 2 $(\boldsymbol{n}=\mathbf{9 )}$ \\
\hline Age $(\mathrm{y})$ & $12.0 \pm 0.4$ & $12.1 \pm 0.5$ \\
Sex $(\mathrm{M}: \mathrm{F})$ & $9: 8$ & $6: 3$ \\
Body Mass $(\mathrm{kg})$ & $49.9 \pm 2.7$ & $48.9 \pm 3.9$ \\
Height $(\mathrm{cm})$ & $154.7 \pm 2.4$ & $154.5 \pm 2.2$ \\
BMI $\left(\mathrm{kg} / \mathrm{m}^{2}\right)$ & $20.8 \pm 0.9$ & $20.4 \pm 1.4$ \\
BMI Percentile & $67.9 \pm 5.9$ & $64.5 \pm 10.8$ \\
Fat Mass $(\%)^{1}$ & $31.4 \pm 2.3$ & $27.4 \pm 2.1$ \\
${\text { Fat Mass }(\mathrm{kg})^{1}}^{1}$ & $16.2 \pm 1.8$ & $13.9 \pm 2.0$ \\
Fat-Free Mass $(\%)$ & $68.6 \pm 2.3$ & $72.6 \pm 2.1$ \\
Fat-Free Mass $(\mathrm{kg})$ & $33.8 \pm 1.6$ & $35.0 \pm 2.2$
\end{tabular}

Data are presented as mean $\pm \mathrm{SEM}^{1}$. Body composition was estimated from the sum of bicep, tricep, suprailiac and subscapular regions skinfold measurements [32,33].

\subsection{Treatment Conditions}

All breakfast meals were isocaloric (450 kcal), matched for 34\% fat content and sodium (909 mg) and are summarized in Table 2. The control breakfast was composed of toasted Wonder ${ }^{\mathrm{TM}}$ White + Fibre bread (Weston Bakeries Ltd., Toronto, ON, Canada), butter (Gay Lea ${ }^{\circledR}$ Foods Co-operative, Mississauga, ON, Canada), and strawberry jam (President's Choice ${ }^{\circledR}$, Brampton, ON, Canada). The egg-based protein breakfasts were served as an egg-omelet with baked home-fried potatoes (donated by McCain Canada Ltd., Florenceville-Bristol, NB, Canada), cheese and ketchup (President's Choice ${ }^{\circledR}$, Brampton, ON, Canada). Egg whites and cheese were used in varying amounts to manipulate protein content while keeping all treatments isocaloric (whey and casein; $18 \%$ in MP and HP; $16 \%$ in LP). Treatment meals were served in three equal portions, each spaced $10 \mathrm{~min}$ apart, providing a total of $30 \mathrm{~min}$ for meal completion. This provided a reasonable amount of time for children to comfortably finish their meal without feeling rushed and reduced the potential for adverse gastrointestinal symptoms (i.e., indigestion, nausea, etc.). All breakfast meals were served to participants in individual cubicles to avoid distractions from other research participants.

Table 2. Description of test treatments.

\begin{tabular}{ccccc}
\hline & Control (C) & Low Protein (LP) & Medium Protein (MP) & High Protein (HP) \\
\hline Food items & $\begin{array}{c}\text { white bread, } \\
\text { butter, jam }\end{array}$ & $\begin{array}{c}\text { egg yolk, egg whites, } \\
\text { butter, cheese, home } \\
\text { fries, ketchup }\end{array}$ & $\begin{array}{c}\text { egg yolk, egg whites, } \\
\text { butter, cheese, home } \\
\text { fries, ketchup }\end{array}$ & $\begin{array}{c}\text { egg yolk, egg whites, } \\
\text { butter, cheese, home } \\
\text { fries, ketchup } \\
\text { Energy content, kcal }\end{array}$ \\
$\begin{array}{c}\text { Protein, } \\
\text { (\% Energy) }\end{array}$ & 750 & 450 & 450 & 450 \\
$\begin{array}{c}\text { Carbohydrate, } \\
\text { (\% Energy) }\end{array}$ & $69(61)$ & $15(13)$ & $30(27)$ & $45(40)$ \\
Fat, g (\% Energy) & $17(34)$ & $61(54)$ & $45(40)$ & $30(27)$ \\
Sodium, mg & 909 & $17(34)$ & $17(34)$ & $17(34)$ \\
Fibre, g & 3 & 909 & 909 & 909 \\
\end{tabular}




\subsection{Visual Analogue Scales}

In experiments 1 and 2, participants were asked to complete visual analogue scales (VAS) for motivation-to-eat and physical comfort; each VAS was a $100 \mathrm{~mm}$ line where they placed a pencil mark to describe their feelings along the continuum. For motivation-to-eat, children described their desire to eat ("Very weak" to "Very strong"), hunger ("Not hungry at all" to "As hungry as I have ever felt"), fullness ("Not full at all" to "Very full"), and prospective food consumption (PFC) ("A large amount" to "Nothing at all") for subjective appetite, as reported [34-37] and validated [27] in our previous studies. A subjective appetite score was calculated from the motivation-to-eat VAS questionnaire using the following formula:

Subjective Appetite $(\mathrm{mm})=[$ desire to eat + hunger $+(100-$ fullness $)+P F C] / 4$.

Subjective thirst was assessed via VAS using the question "How thirsty do you feel?" anchored by "Not thirsty at all" and "As thirsty as I have ever felt". The pleasantness of the meals was assessed via VAS with the question "How pleasant did you find the breakfast/pizza?"

\subsection{Experimental Design}

Both experiments used randomized, within-subject, repeated-measures designs. Prior to participating in the study sessions, each participant attended a screening visit at Ryerson University where written consent from parents/guardians and assent from the child were obtained. Anthropometrics and body composition were measured, pizza preference for the ad libitum test meal was recorded and children were familiarized with the facility and study protocols. Each child's height $(\mathrm{m})$ and mass $(\mathrm{kg})$ were measured, body mass index $\left(\mathrm{kg} / \mathrm{m}^{2}\right)$ was calculated and percentiles were obtained from the Centers for Disease Control and Prevention (CDC) growth charts [33]. Skinfold measurements (mm) at the tricep, bicep, suprailiac and subscapular were obtained using a Harpenden skinfold caliper (Cambridge Scientific Industries, Cambridge, MD, USA) to the nearest $0.1 \mathrm{~mm}$ by a trained technician. The mean of three consecutive skinfold measurements was used to determine percent body fat and fat-free mass using age- and sex-specific regression equations (Table 1) [38].

\subsubsection{Experiment 1}

Each participant arrived at the laboratory between 0700 and $0930 \mathrm{~h}$ on each of their four test visits, at least one week apart, having been asked to fast for 10-12 h. Upon arrival, baseline (0 min) subjective appetite was measured via VAS [27,39], and blood glucose (BG) was measured via finger prick. Test sessions were rescheduled for participants who reported on a compliance survey not having fasted or whose BG exceeded $5.5 \mathrm{mmol} / \mathrm{L}$. Participants then consumed, in a random order, one of four isocaloric breakfast meals $(450 \mathrm{kcal})$ of varying protein content within $30 \mathrm{~min}$ : an egg-omelet with a side of home-fried potatoes (15 $\mathrm{g}$ [low protein, LP], $30 \mathrm{~g}$ [medium protein, MP], $45 \mathrm{~g}$ [high protein, $\mathrm{HP}]$ ), or white bread with butter and jam (7 $\mathrm{g}$ [control, C]; Table 2). Subjective appetite was assessed via VAS immediately following breakfast consumption (30 min), and at regular intervals for a total of $4 \mathrm{~h}$ $(60,90,120,180$, and $240 \mathrm{~min})$. Blood glucose was measured immediately after breakfast consumption (30 $\mathrm{min})$, and at regular intervals for $4 \mathrm{~h}(60,120,180$, and $240 \mathrm{~min})$. Three and a half hours from the end of breakfast consumption, participants were given an ad libitum pizza lunch with instructions to eat until they were comfortably full. Both breakfast and lunch meals were served with $500 \mathrm{~mL}$ bottled spring water (Nestlé Pure Life ${ }^{\circledR}$, Guelph, ON, Canada). The pleasantness of the test meals was assessed using VAS [27], and pizza preferences were standardized within each participant across all sessions. Subjective physical comfort was assessed using VAS after each BG measurement.

\subsubsection{Experiment 2}

Participants arrived at the lab between 0730 and $0800 \mathrm{~h}$ following a 10-12 $\mathrm{h}$ overnight fast and having refrained from physical exertion for $24 \mathrm{~h}$. Test sessions were rescheduled if participants did 
not comply with the pre-test protocol. Participants rested for $30 \mathrm{~min}$, followed by a measurement of resting energy expenditure (REE) for $30 \mathrm{~min}$ using indirect calorimetry (Parvo Medics TrueOne 2400). Participants consumed, in random order, one of two test breakfasts (HP or control) within $30 \mathrm{~min}$, followed by energy expenditure measurements for $5 \mathrm{~h}$. Diet-induced thermogenesis was calculated as the increase in energy expenditure above baseline REE over the $5 \mathrm{~h}$. Respiratory exchange ratio (RER) was determined to assess the impact of the breakfast meals on substrate utilization. Subjective appetite was determined at baseline, immediately after breakfast consumption, and every hour for $5 \mathrm{~h}$.

\subsection{Food Intake}

In experiment 1, ad libitum FI was measured from a pizza meal and FI was determined by weighing the meal before and after serving [34,35]. The pizzas were small and round (5-inch, $200 \mathrm{kcal})$ and available in two varieties with similar nutritional composition (Deep 'N Delicious Pepperoni or Three Cheese, McCain Canada Ltd., Florenceville-Bristol, NB, Canada). Each pizza lacked an outer crust, which resulted in a more uniform distribution of energy [27,39]. The net weight of the test meal was converted to kcal based on manufacturer information. Pizza preference was determined at the screening visit. Three trays of pizza $(\sim 1800 \mathrm{kcal}$ in total) with each tray containing three pizzas, two of their first choice and one of their second choice, were provided and cut into equal pieces. Participants were informed that additional hot tray replacements would be presented in 10 min intervals and to eat until comfortably full, providing a total of $30 \mathrm{~min}$ for meal completion. This provided a reasonable amount of time for children to comfortably finish their meal without feeling rushed and reduced the potential for adverse gastrointestinal symptoms (i.e., indigestion, nausea, etc.) Participants ate their meal in individual cubicles, which eliminated distractions from other research participants. Water intake $(\mathrm{g})$ was determined by weighing each water bottle before and after the test meal.

\subsection{Glycemic Response}

In experiment 1 , children's fingers were sanitized with single-use alcohol wipes and capillary blood was collected at six time points using a single-use, auto-disabling finger-prick device. The blood sample was analyzed immediately for BG using a commercially available glucometer (Accu-Chek ${ }^{\circledR}$ Aviva, Toronto, ON, Canada).

\subsection{Diet-induced Thermogenesis}

In experiment 2, participants rested in a supine position for $30 \mathrm{~min}$ to reach a steady resting state in an isolated, dimly lit room under controlled temperature and humidity conditions. Resting energy expenditure was determined by indirect calorimetry (ParvoMedics TrueOne2400 automated metabolic gas analysis system, ParvoMedics, Sandy, UT, USA) under a ventilated hood for 30 min. Participants were instructed to remain awake and to not move, fidget or talk while under the ventilated hood. Resting energy expenditure was calculated based on the volume of oxygen consumed (VO2) and volume of carbon dioxide (VCO2) produced using Weir's formula [20]: REE (kcal/day) = 5.616 * VO2 (mL/min) $+1.584 * \mathrm{VCO} 2(\mathrm{~mL} / \mathrm{min})$ [40]. Steady state was defined as a stable VO2 and respiratory exchange ratio (RER) within 10\% and 5\% deviation, respectively, for a minimum of $10 \mathrm{~min}$. Measurements from the first 5 min were discarded to account for acclimatization to the ventilated hood system.

After REE was measured, participants consumed either a control or HP breakfast (Table 2) followed by a 10 min rest period. Respiratory gases were measured in 30 min intervals for $5 \mathrm{~h}$ under the ventilated hood using the indirect calorimeter, with a $30 \mathrm{~min}$ break between measurements. Participants could use the restroom, rest quietly, or watch TV during $30 \mathrm{~min}$ break periods. Diet-induced thermogenesis $(\mathrm{kcal} / \mathrm{h})$ was calculated as the increase in energy expenditure above baseline REE for $300 \mathrm{~min}$. Respiratory exchange ratio was monitored to assess the impact of the test breakfast on substrate utilization. Energy expenditure and substrate oxidation rates for each hourly interval were 
calculated using average VO2 and VCO2 measurements [40]. Substrate oxidation was calculated using the following equations [41]:

$$
\begin{aligned}
& \text { Carbohydrate oxidation }=\mathrm{F}_{\mathrm{g}} \times \frac{\mathrm{VO}_{2}}{0.746} \text {, where } \mathrm{F}_{\mathrm{g}}=\frac{\mathrm{RQ}-0.705}{1-0.705} \\
& \text { Fat oxidation }=\mathrm{F}_{\mathrm{f}} \times \frac{\mathrm{VO}_{2}}{2.03} \text { where } \mathrm{Ff}=1-\mathrm{F}_{\mathrm{g}}
\end{aligned}
$$

\subsection{Statistical Analyses}

In experiment 1, a two-way repeated measure analysis of variance (ANOVA), adjusted for multiple comparisons using a Tukey post-hoc was used to determine the effects of breakfast treatments (LP, MP, $\mathrm{HP}$, control) and time on change from baseline subjective appetite and absolute BG. Change from baseline subjective appetite was used to correct for participant differences at baseline and was calculated by subtracting the baseline measurement from subsequent measurements. A one-way ANOVA using a Tukey post-hoc correction, was used to determine the effect of treatment on blood glucose incremental area under the curve (BG iAUC), FI, water intake, and pleasantness (breakfast and lunch). Blood glucose iAUC was calculated using the trapezoid method [42]. In experiment 2, a two-way repeated measures ANOVA, corrected for multiple comparison using a Tukey post-hoc, was used to assess the effect of treatment (HP, control) and time (over $5 \mathrm{~h}$ ) on DIT (kcal/h) and change from baseline subjective appetite. Diet-induced thermogenesis (kcal), RER, carbohydrate oxidation $(\mathrm{g} / \mathrm{h})$, and fat oxidation $(\mathrm{g} / \mathrm{h})$ were assessed by paired t-test. Pearson correlations were used to determine associations between DIT and subjective appetite (experiment 2). All results are expressed as mean \pm SEM. Statistical analyses were conducted using SAS version 9.3 (SAS Institute Inc., Carey, NC, USA), with significance defined as $p<0.05$.

\section{Results}

\subsection{Experiment 1}

\subsubsection{Food and Water Intake}

There was a main effect of breakfast meal on FI $(p<0.05)$. Food intake was lower following the HP breakfast $(858 \pm 88 \mathrm{kcal})$ than control $(1084 \pm 83 \mathrm{kcal}, p=0.005, n=17)$ and LP $(1062 \pm 93 \mathrm{kcal}$, $p=0.01, n=17$ ) treatments (Table 3). Food intake was similar following consumption of the control, LP and MP meals. There was no significant effect of breakfast meal on water intake $(p=0.21)$.

Table 3. The effect of test meals on food and water intake, and subjective pleasantness (experiment 1),

\begin{tabular}{|c|c|c|c|c|}
\hline & Control (C) & Low Protein (LP) & Medium Protein (MP) & High Protein (HP) \\
\hline \multicolumn{5}{|l|}{ Experiment 1} \\
\hline Food intake (kcal) & $1084 \pm 83^{a}$ & $1062 \pm 93^{a}$ & $1001 \pm 85^{a, b}$ & $858 \pm 88^{b}$ \\
\hline Pleasantness of breakfast (mm) & $72 \pm 8$ & $84 \pm 4$ & $80 \pm 6$ & $74 \pm 5$ \\
\hline Pleasantness of pizza lunch (mm) & $83 \pm 6$ & $89 \pm 3$ & $89 \pm 4$ & $91 \pm 3$ \\
\hline \multicolumn{5}{|l|}{ Experiment 2} \\
\hline Mean respiratory exchange ratio & $0.86 \pm 0.01$ & & & $0.85 \pm 0.01$ \\
\hline Mean carbohydrate oxidation $(\mathrm{g} / \mathrm{h})$ & $8.6 \pm 0.4^{\mathrm{a}}$ & & & $7.6 \pm 0.4^{\mathrm{b}}$ \\
\hline Mean fat oxidation $(\mathrm{g} / \mathrm{h})$ & $2.9 \pm 0.2^{\mathrm{a}}$ & & & $3.9 \pm 0.2^{b}$ \\
\hline
\end{tabular}
and diet-induced thermogenesis and substrate utilization (experiment 2).

Experiment 1: $n=17$, Experiment 2: $n=9$; values are expressed as mean \pm SEM. Mean values with different letters denote a significant difference $(p<0.05)$ using a one-way ANOVA with a Tukey post hoc correction (experiment 1$)$ and paired t-tests (experiment 2). 


\subsubsection{Subjective Ratings from Visual Analogue Scales}

An effect of time $(p<0.0001)$ and treatment $(p<0.0001)$ were observed for change from baseline subjective appetite, but no time by treatment interaction $(p=1.000)$. Change from baseline subjective appetite after LP $(p=0.004), \mathrm{MP}(p<0.0001)$ and HP $(p<0.0001)$ were lower than the control (Figure 1 ; $n=17)$. Neither pleasantness of the breakfast $(p=0.352)$ nor pizza lunch $(p=0.319)$ were affected by treatment (Table 3).

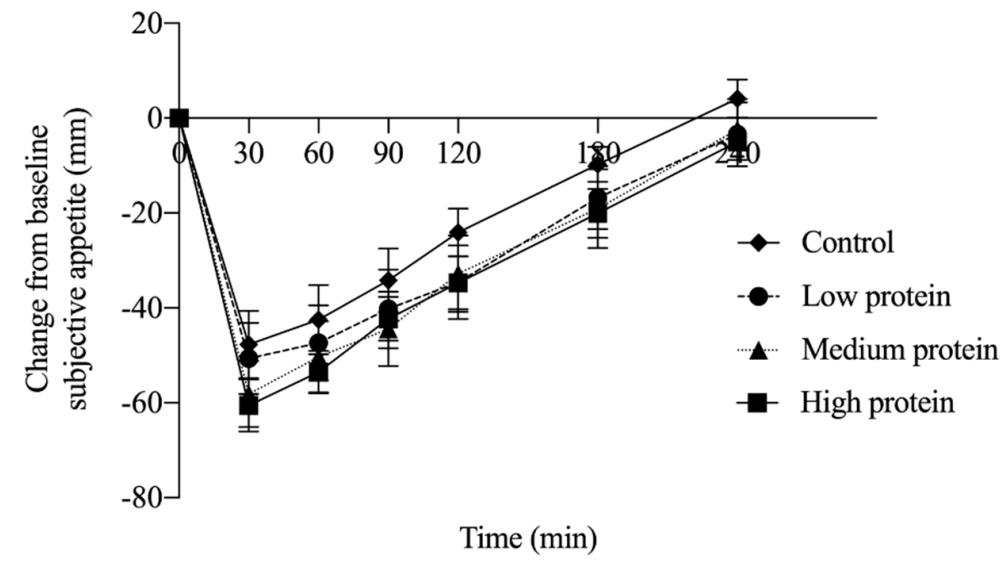

Figure 1. Change from baseline subjective appetite among treatments containing varying amounts of protein (experiment $1 ; n=17)$. No interaction of time and treatment was observed $(p=1.000)$, however subjective appetite following the control treatment was significantly higher than $\operatorname{LP}(p=0.0008)$, MP $(p<0.0001)$ and HP $(p<0.0001)$ treatments.

\subsubsection{Glycemic Response}

Two participants were excluded from analysis across all time points as insufficient blood was collected to quantify BG. No main effect of treatment $(p=0.11)$ on glycemic response was observed; however, main effects of time $(p<0.0001)$ and time by treatment interaction $(p<0.0001)$ were detected. Absolute BG concentration at 60 min was significantly lower following the $\mathrm{MP}(p=0.006)$ and HP $(p<0.0001)$ breakfast treatments compared to the control breakfast (Figure 2; $n=15)$. No other significant differences were observed at other measurement time points. There was no significant effect of treatment on BG iAUC $(p=0.61)$.

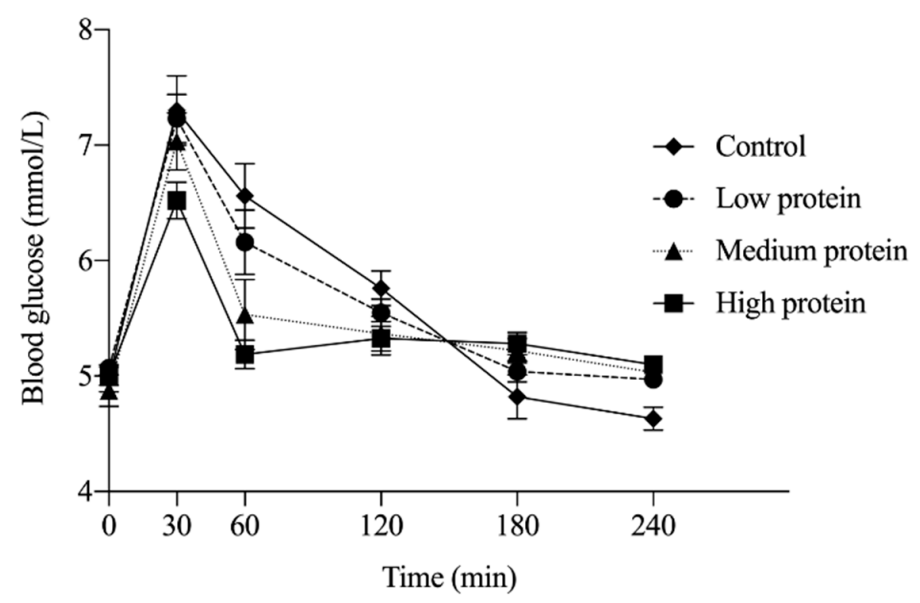

Figure 2. Glycemic response over $240 \mathrm{~min}$ following breakfast consumption; $n=15$. At $60 \mathrm{~min}$, blood glucose following consumption of the medium protein and high protein breakfast was significantly lower (MP, $p=0.0064$; HP, $p<0.0001$ ) compared with the control treatment by two-way repeated measures ANOVA with a Tukey post hoc correction. Values are expressed as mean \pm SEM. 


\subsection{Experiment 2}

\subsubsection{Subjective Ratings from Visual Analogue Scales}

There were no main effects of treatment $(p=0.55)$, time $(p=0.87)$, or a time by treatment interaction $(p=0.99)$ on change from baseline subjective appetite (Figure 3). Similarly, no significant association was observed between subjective appetite and DIT following consumption of either control $(\mathrm{r}=-0.3$, $p=0.44, n=9)$ or HP breakfast meals over the $5 \mathrm{~h}$ measurement period $(\mathrm{r}=-0.16, p=0.69, n=9)$.

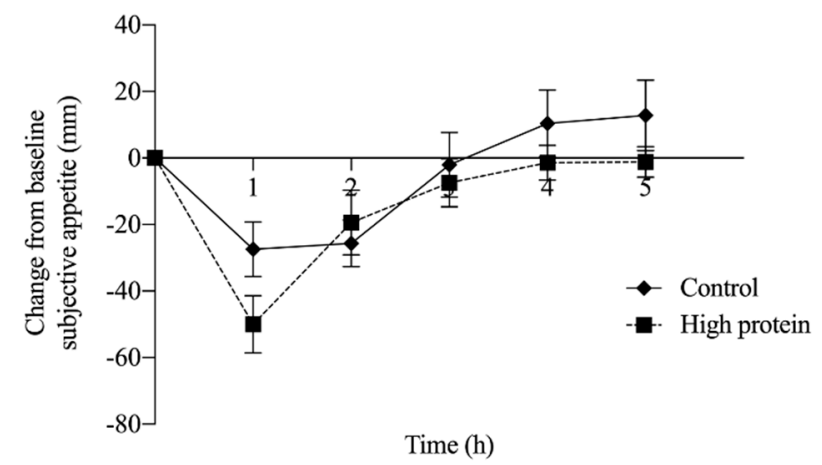

Figure 3. Change from baseline subjective appetite over $5 \mathrm{~h}$, after consumption of the high protein or control meal (experiment 2; $n=9$ ). No significant differences were observed between treatment $(p=0.55)$, time $(p=0.87)$ or time by treatment interaction $(p=0.99)$ following consumption of the high protein breakfast compared with the control breakfast.

\subsubsection{Diet-Induced Thermogenesis and Substrate Utilization}

Diet-induced thermogenesis (Figure 4a) was affected by both treatment $(p<0.0001)$ and time $(p<0.05)$ over the $5 \mathrm{~h}$ study period, but there was no significant time by treatment interaction $(p=0.26)$. Consumption of the HP breakfast resulted in greater DIT than the control treatment. Total DIT after the HP breakfast was $52.1 \pm 5.7 \mathrm{kcal}$ (Figure $4 \mathrm{~b}$ ), which was approximately $30 \mathrm{kcal}$ higher than DIT following consumption of the control treatment $(22.6 \pm 5.1 \mathrm{kcal} ; p<0.0001)$.

Furthermore, over the $5 \mathrm{~h}$ measurement period, there was greater fat oxidation (HP: $3.9 \pm 0.2 \mathrm{~g} / \mathrm{h}$ vs. C: $2.9 \pm 0.2 \mathrm{~g} / \mathrm{h} ; p<0.0001$ ) and lower carbohydrate oxidation (HP: $7.6 \pm 0.4 \mathrm{~g} / \mathrm{h}$ vs. C: $8.6 \pm 0.4 \mathrm{~g} / \mathrm{h}$; $p=0.04$ ) following consumption of the HP breakfast than the control breakfast. Conversely, the control breakfast stimulated a greater rate of carbohydrate oxidation compared to the HP treatment (Table 3).

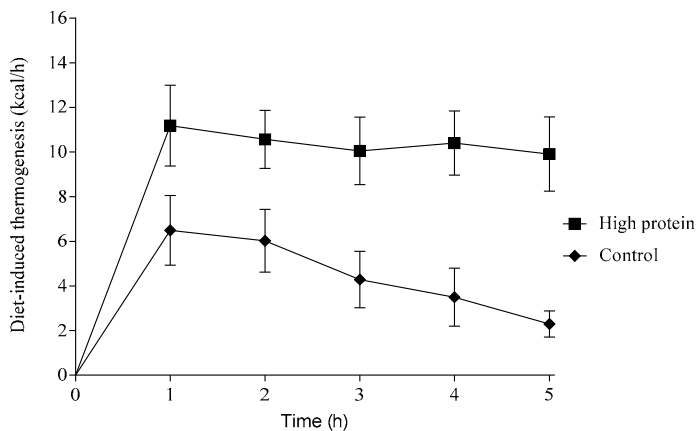

(a)

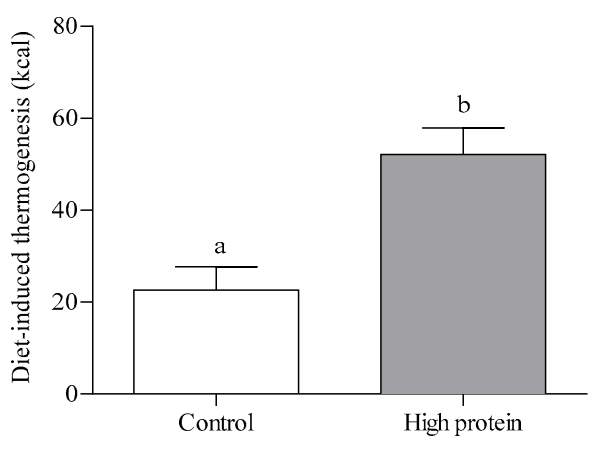

(b)

Figure 4. Diet-induced thermogenesis over $5 \mathrm{~h}$ following consumption of the HP or control meal (experiment 2; $n=9$ ). (a) Change from baseline DIT over $5 \mathrm{~h}$ in children. There was a significant main effect of treatment $(p<0.0001)$ and time $(p<0.05)$, but no significant time by treatment interaction $(p=0.26)$. (b) Total DIT over $5 \mathrm{~h}$ following consumption of HP or control breakfast. DIT was significantly higher following consumption of HP $(52.1 \pm 5.7 \mathrm{kcal})$ compared with the control breakfast $(22.6 \pm 5.1 \mathrm{kcal}$; $p<0.0001, n=9)$. Mean values with different letters denote a significant difference $(p<0.05)$. 


\section{Discussion}

The present study fills an important knowledge gap in our understanding of how dietary protein affects satiety and selected metabolic processes in children. Our results show that dietary protein intake affects both sides of the energy balance equation - energy intake (subjective appetite and FI) and energy expenditure (DIT). Cumulatively, these results suggest that a higher protein intake at breakfast decreases short-term FI and increases energy expenditure compared with lower protein meals.

Our findings highlight the importance of considering protein quantity when delineating the influence on satiety and FI. In experiment 1, while all test treatments suppressed subjective appetite compared to the control meal, only the HP (45 g) breakfast suppressed short-term FI compared with the LP and control treatments. Similar to the results of this study, FI following an egg-based breakfast containing $18 \mathrm{~g}$ of protein did not differ from a waffle-based breakfast ( $3 \mathrm{~g}$ protein) in children 8-12 y [43]. However, studies in children showed breakfast meals with greater than $30 \mathrm{~g}$ of protein decreased FI at lunch $[23,24]$, suggesting that a protein intake of less than $30 \mathrm{~g}$ may not be enough to suppress FI.

Higher DIT was observed over $5 \mathrm{~h}$ following ingestion of the HP breakfast (45 g) than the isocaloric control breakfast $(7 \mathrm{~g})$. Studies in adults have reported that protein-rich meals (30-100 g of protein) produce larger diet-induced thermogenic effects compared to carbohydrates or fat $[15,16,44]$. This may reflect the lack of storage capacity for dietary protein, necessitating immediate processing [17] or higher ATP utilization for amino acids than glucose during metabolism [45]. In contrast to our results, a study in children 8-12 y found no difference in DIT following isocaloric breakfasts (340 kcal) containing $18 \mathrm{~g}$ and $3 \mathrm{~g}$ of protein [43]. This may reflect the lower protein content used or methodological differences (length of measurement period and energy content/macronutrient composition of meals) [46]. Furthermore, the type of protein may also be an important factor as high quantities ( $>30 \mathrm{~g}$ ) of complete proteins such as eggs create a surge in aminoacidemia which can drive thermogenesis [47]. Indeed, the control meal contained plant-based protein and studies suggest plant proteins may have a weaker effect on satiety than animal proteins $[48,49]$. Veldhorst et al. found that at $10 \%$ of energy from dietary protein there was an effect of protein source on subjective appetite, but not at $25 \%$ of energy suggesting that appetite response to protein and protein source is dependent on dose [49].

Increased postprandial glycemia is implicated in increased fat cell deposition and obesity [50]. The MP and HP breakfast treatments in our study resulted in significantly lower BG concentrations at $60 \mathrm{~min}$ compared to the control treatment. This result is likely due to less availability of carbohydrates in the MP and HP meals, and therefore reduced glucose response. Similarly, in adults, egg consumption at breakfast resulted in less variation of plasma glucose and insulin, and subsequently reduced energy intake over $24 \mathrm{~h} \mathrm{[51].} \mathrm{These} \mathrm{findings} \mathrm{may} \mathrm{also} \mathrm{be} \mathrm{explained} \mathrm{by} \mathrm{the} \mathrm{effect} \mathrm{of} \mathrm{greater} \mathrm{quantities} \mathrm{of} \mathrm{protein;}$ it has been shown that protein can attenuate glycemic response via the stimulation of insulin secretion and ultimately slowing gastric emptying [52-54].

Increasing dietary carbohydrate intake has been shown to increase carbohydrate oxidation and lower fat oxidation [55], while increased fat consumption may stimulate only modest increases in fat oxidation [16,29]. Indeed, fat intake exceeding the body's ability to oxidize it results in a positive fat balance and may contribute to weight gain [56]. In the current study, the control and HP meals had differing percentages of protein ( $6 \%$ vs. $40 \%)$ and carbohydrates $(61 \%$ vs. $27 \%)$, but fat percentage was the same (34\%). Interestingly, the HP breakfast resulted in higher fat oxidation than carbohydrate oxidation, which reflects the difference in available energy sources between the two diets.

Although the current study had many strengths, there are several limitations. First, our study included a small sample size and was limited to only having short-term FI measurements. Second, while breakfast meals differing in protein content did not affect rest of day energy intake among adults [4] or adolescents [24], this has not been explored in younger children. Third, isocaloric treatment conditions were characterized by percentage of increasing protein content, however as protein content increased, carbohydrate content decreased. Therefore, while previous literature suggests the results observed in the present study can be attributed to protein content, the variation in carbohydrate content 
is confounding. A future study could resolve this issue by examining the effects of breakfast meals with increasing protein content with variable total energy on subjective appetite and DIT. Similarly, since all protein treatments used potatoes instead of bread as the carbohydrate source, it is more challenging to identify protein-specific effects on components of energy balance or metabolism. The white potato content of breakfast may have contributed to both appetite and FI suppression, as white potatoes have been shown to increase satiety in both adults [57] and children [58,59]. Additionally, while the largest protein meal (45 g) reduced short-term FI and increased DIT, the feasibility of parents consistently preparing meals higher in protein in free-living conditions is unknown and should be addressed in future experimental studies. Lastly, the assessment of biomarkers such as post-prandial gastrointestinal hormone concentrations or changes in plasma amino acids [54,60-62] would have provided valuable insight into potential physiological mechanisms of changes in subjective appetite and FI. Increasing the dietary protein content at the expense of carbohydrates in meals has a dose-dependent-like effect on satiety, glucagon-like-peptide-1 (GLP-1), peptide YY and glucagon [63]. Indeed, greater suppression of subjective ratings of hunger and ad libitum food intake $90 \mathrm{~min}$ after consumption of a whey protein preload ( $48 \mathrm{~g}$ ) has been associated with increases in total plasma amino acids, cholecystokinin, and GLP-1 [64].

\section{Conclusions}

In conclusion, the HP diet increased satiety and DIT, and suppressed short-term FI in children 9-14 y. Future longitudinal studies are needed to assess the significance of consuming HP diets on promoting healthier body weights in children.

Author Contributions: The authors confirm for all experiments that all measures, conditions, and data exclusions are reported. Conceptualization, N.B.; recruitment and collection of data, T.F., V.C.H.W.; formal analysis, T.F., V.C.H.W., N.R.B., A.S., K.S., and N.B.; writing-original draft preparation, review and editing, T.F., V.C.H.W., J.O.T.d.Z., N.R.B., D.R., K.S., S.C. and N.B. All authors have read and agreed to the published version of the manuscript.

Funding: This research was funded by The Obesity Society/Egg Nutrition Center research grant.

Conflicts of Interest: The authors declare no conflict of interest.

\section{References}

1. De Onis, M.; Blossner, M.; Borghi, E. Global prevalence and trends of overweight and obesity among preschool children. Am. J. Clin. Nutr. 2010, 92, 1257-1264. [CrossRef]

2. Veldhorst, M.; Smeets, A.; Soenen, S.; Hochstenbach-Waelen, A.; Hursel, R.; Diepvens, K.; Lejeune, M.; Luscombe-Marsh, N.; Westerterp-Plantenga, M. Protein-induced satiety: Effects and mechanisms of different proteins. Physiol. Behav. 2008, 94, 300-307. [CrossRef]

3. Weigle, D.S.; Breen, P.A.; Matthys, C.C.; Callahan, H.S.; Meeuws, K.E.; Burden, V.R.; Purnell, J.Q. A high-protein diet induces sustained reductions in appetite, ad libitum caloric intake, and body weight despite compensatory changes in diurnal plasma leptin and ghrelin concentrations. Am. J. Clin. Nutr. 2005, 82, 41-48. [CrossRef]

4. Stubbs, R.J.; van Wyk, M.C.; Johnstone, A.M.; Harbron, C.G. Breakfasts high in protein, fat or carbohydrate: Effect on within-day appetite and energy balance. Eur. J. Clin. Nutr. 1996, 50, 409-417.

5. Clifton, P.M.; Condo, D.; Keogh, J.B. Long term weight maintenance after advice to consume low carbohydrate, higher protein diets-a systematic review and meta analysis. Nutr. Metab. Cardiovasc. Dis. 2014, 24, 224-235. [CrossRef]

6. Wright, M.; Sotres-Alvarez, D.; Mendez, M.A.; Adair, L. The association of trajectories of protein intake and age-specific protein intakes from 2 to 22 years with BMI in early adulthood. Br. J. Nutr. 2017, 117, 750-758. [CrossRef]

7. Papadaki, A.; Linardakis, M.; Larsen, T.M.; van Baak, M.A.; Lindroos, A.K.; Pfeiffer, A.F.; Martinez, J.A.; Handjieva-Darlenska, T.; Kunesová, M.; Holst, C.; et al. The effect of protein and glycemic index on children's body composition: The DiOGenes randomized study. Pediatrics 2010, 126, e1143-e1152. [CrossRef] 
8. Szajewska, H.; Ruszczynski, M. Systematic review demonstrating that breakfast consumption influences body weight outcomes in children and adolescents in Europe. Crit. Rev. Food Sci. Nutr. 2010, 50, 113-119. [CrossRef]

9. Skov, A.R.; Toubro, S.; Ronn, B.; Holm, L.; Astrup, A. Randomized trial on protein vs carbohydrate in ad libitum fat reduced diet for the treatment of obesity. Int. J. Obes. Relat. Metab. Disord. 1999, 23, 528-536. [CrossRef]

10. Layman, D.K. The role of leucine in weight loss diets and glucose homeostasis. J. Nutr. 2003, 133, 261 S-267S. [CrossRef]

11. Layman, D.K.; Baum, J.I. Dietary protein impact on glycemic control during weight loss. J. Nutr. 2004, 134, 968S-973S. [CrossRef] [PubMed]

12. Mikkelsen, P.B.; Toubro, S.; Astrup, A. Effect of fat-reduced diets on 24-h energy expenditure: Comparisons between animal protein, vegetable protein, and carbohydrate. Am. J. Clin. Nutr. 2000, 72, 1135-1141. [CrossRef] [PubMed]

13. Westerterp, K.R. Diet induced thermogenesis. Nutr. Metab. 2004, 1, 5. [CrossRef]

14. Halton, T.L.; Hu, F.B. The effects of high protein diets on thermogenesis, satiety and weight loss: A critical review. J. Am. Coll. Nutr. 2004, 23, 373-385. [CrossRef]

15. Crovetti, R.; Porrini, M.; Santangelo, A.; Testolin, G. The influence of thermic effect of food on satiety. Eur. J. Clin. Nutr. 1998, 52, 482-488. [CrossRef]

16. Tentolouris, N.; Pavlatos, S.; Kokkinos, A.; Perrea, D.; Pagoni, S.; Katsilambros, N. Diet-induced thermogenesis and substrate oxidation are not different between lean and obese women after two different isocaloric meals, one rich in protein and one rich in fat. Metabolism 2008, 57, 313-320. [CrossRef]

17. Robinson, S.M.; Jaccard, C.; Persaud, C.; Jackson, A.A.; Jequier, E.; Schutz, Y. Protein turnover and thermogenesis in response to high-protein and high-carbohydrate feeding in men. Am. J. Clin. Nutr. 1990, 52, 72-80. [CrossRef]

18. Lorenzen, J.; Frederiksen, R.; Hoppe, C.; Hvid, R.; Astrup, A. The effect of milk proteins on appetite regulation and diet-induced thermogenesis. Eur. J. Clin. Nutr. 2012, 66, 622-627. [CrossRef]

19. Leidy, H.J.; Clifton, P.M.; Astrup, A.; Wycherley, T.P.; Westerterp-Plantenga, M.S.; Luscombe-Marsh, N.D.; Woods, S.C.; Mattes, R.D. The role of protein in weight loss and maintenance. Am. J. Clin. Nutr. 2015, 101, 1320S-1329S. [CrossRef]

20. Paddon-Jones, D.; Leidy, H. Dietary protein and muscle in older persons. Curr. Opin. Clin. Nutr. Metab. Care 2014, 17, 5-11. [CrossRef]

21. Bellissimo, N.; Desantadina, M.V.; Pencharz, P.B.; Berall, G.B.; Thomas, S.G.; Anderson, G.H. A comparison of short-term appetite and energy intakes in normal weight and obese boys following glucose and whey-protein drinks. Int. J. Obes. 2008, 32, 362-371. [CrossRef] [PubMed]

22. Kral, T.V.; Bannon, A.L.; Chittams, J.; Moore, R.H. Comparison of the satiating properties of egg-versus cereal grain-based breakfasts for appetite and energy intake control in children. Eat. Behav. 2016, 20, 14-20. [CrossRef] [PubMed]

23. Leidy, H.J.; Ortinau, L.C.; Douglas, S.M.; Hoertel, H.A. Beneficial effects of a higher-protein breakfast on the appetitive, hormonal, and neural signals controlling energy intake regulation in overweight/obese, “breakfast-skipping," late-adolescent girls. Am. J. Clin. Nutr. 2013, 97, 677-688. [CrossRef] [PubMed]

24. Leidy, H.J.; Racki, E.M. The addition of a protein-rich breakfast and its effects on acute appetite control and food intake in 'breakfast-skipping' adolescents. Int. J. Obes. 2010, 34, 1125-1133. [CrossRef] [PubMed]

25. Bendtsen, L.Q.; Lorenzen, J.K.; Bendsen, N.T.; Rasmussen, C.; Astrup, A. Effect of dairy proteins on appetite, energy expenditure, body weight, and composition: A review of the evidence from controlled clinical trials. Adv. Nutr. 2013, 4, 418-438. [CrossRef]

26. Acheson, K.J.; Blondel-Lubrano, A.; Oguey-Araymon, S.; Beaumont, M.; Emady-Azar, S.; Ammon-Zufferey, C.; Monnard, I.; Pinaud, S.; Nielsen-Moennoz, C.; Bovetto, L. Protein choices targeting thermogenesis and metabolism. Am. J. Clin. Nutr. 2011, 93, 525-534. [CrossRef]

27. Bellissimo, N.; Thomas, S.G.; Pencharz, P.B.; Goode, R.C.; Anderson, G.H. Reproducibility of short-term food intake and subjective appetite scores after a glucose preload, ventilation threshold, and body composition in boys. Appl. Physiol. Nutr. Metab. 2008, 33, 326-337. [CrossRef]

28. Bessard, T.; Schutz, Y.; Jéquier, E. Energy expenditure and postprandial thermogenesis in obese women before and after weight loss. Am. J. Clin. Nutr. 1983, 38, 680-693. [CrossRef] 
29. Maffeis, C.; Schutz, Y.; Grezzani, A.; Provera, S.; Piacentini, G.; Tato, L. Meal-induced thermogenesis and obesity: Is a fat meal a risk factor for fat gain in children? J. Clin. Endocrinol. Metab. 2001, 86, 214-219. [CrossRef]

30. Maffeis, C.; Schutz, Y.; Zoccante, L.; Pinelli, L. Meal-induced thermogenesis in obese children with or without familial history of obesity. Eur. J. Pediatr. 1993, 152, 128-131. [CrossRef]

31. Tounian, P.; Girardet, J.P.; Carlier, L.; Frelut, M.L.; Veinberg, F.; Fontaine, J.L. Resting energy expenditure and food-induced thermogenesis in obese children. J. Pediatr. Gastroenterol. Nutr. 1993, 16, 451-457. [CrossRef]

32. Heymsfield, S.B.; Williams, P.J. Nutritional assessment by clinical and biochemical methods. In Modern Nutrition in Health and Disease; Shils, M.E., Young, V.R., Eds.; Lae and Febiger: Philadelphia, PA, USA, 1988; pp. 817-870.

33. Ogden, C.L.; Kuczmarski, R.J.; Flegal, K.M.; Mei, Z.; Guo, S.; Wei, R.; Grummer-Strawn, L.M.; Curtin, L.R.; Roche, A.F.; Johnson, C.L. Centers for Disease Control and Prevention 2000 growth charts for the United States: Improvements to the 1977 National Center for Health Statistics version. Pediatrics 2002, 109, 45-60. [CrossRef]

34. De Totosy Zepetnek, J.O.; Pollard, D.; Welch, J.M.; Rossiter, M.; Faghih, S.; Bellissimo, N. Pre-meal screen-time activities increase subjective emotions, but not food intake in young girls. Appetite 2017, 111,32-37. [CrossRef]

35. Van Engelen, M.; Khodabandeh, S.; Akhavan, T.; Agarwal, J.; Gladanac, B.; Bellissimo, N. Effect of sugars in solutions on subjective appetite and short-term food intake in 9- to 14-year-old normal weight boys. Eur. J. Clin. Nutr. 2014, 68, 773-777. [CrossRef]

36. Gheller, B.J.; Totosy de Zepetnek, J.O.; Welch, J.M.; Rossiter, M.D.; Luhovyy, B.L.; Brett, N.R.; Bellissimo, N. Effect of video game playing and a glucose preload on subjective appetite, subjective emotions, and food intake in overweight and obese boys. Appl. Physiol. Nutr. Metab. 2019, 44, 248-254. [CrossRef]

37. Bennett, L.J.; Totosy de Zepetnek, J.O.; Brett, N.R.; Poirier, K.; Guo, Q.; Rousseau, D.; Bellissimo, N. Effect of Commercially Available Sugar-Sweetened Beverages on Subjective Appetite and Short-Term Food Intake in Girls. Nutrients 2018, 10, 394. [CrossRef]

38. Brook, C.G. Determination of body composition of children from skinfold measurements. Arch. Dis. Child. 1971, 46, 182-184. [CrossRef] [PubMed]

39. Bellissimo, N.; Thomas, S.G.; Goode, R.C.; Anderson, G.H. Effect of short-duration physical activity and ventilation threshold on subjective appetite and short-term energy intake in boys. Appetite 2007, 49, 644-651. [CrossRef] [PubMed]

40. Weir, J.B. New methods for calculating metabolic rate with special reference to protein metabolism. J. Physiol. 1949, 109, 1-9. [CrossRef] [PubMed]

41. Jequier, E.; Felber, J.P. Indirect calorimetry. Baillieres Clin. Endocrinol. Metab. 1987, 1, 911-935. [CrossRef]

42. Wolever, T.M.; Jenkins, D.J.; Jenkins, A.L.; Josse, R.G. The glycemic index: Methodology and clinical implications. Am. J. Clin. Nutr. 1991, 54, 846-854. [CrossRef] [PubMed]

43. Baum, J.I.; Gray, M.; Binns, A. Breakfasts Higher in Protein Increase Postprandial Energy Expenditure, Increase Fat Oxidation, and Reduce Hunger in Overweight Children from 8 to 12 Years of Age. J. Nutr. 2015, 145, 2229-2235. [CrossRef] [PubMed]

44. Neumann, B.L.; Dunn, A.; Johnson, D.; Adams, J.; Baum, J.I. Breakfast Macronutrient Composition Influences Thermic Effect of Feeding and Fat Oxidation in Young Women Who Habitually Skip Breakfast. Nutrients 2016, 8, 490. [CrossRef] [PubMed]

45. Van Milgen, J. Modeling biochemical aspects of energy metabolism in mammals. J. Nutr. 2002, 132, 3195-3202. [CrossRef] [PubMed]

46. Granata, G.P.; Brandon, L.J. The thermic effect of food and obesity: Discrepant results and methodological variations. Nutr. Rev. 2002, 60, 223-233. [CrossRef]

47. Kassis, A.; Godin, J.-P.; Moille, S.E.; Nielsen-Moennoz, C.; Groulx, K.; Oguey-Araymon, S.; Praplan, F.; Beaumont, M.; Sauser, J.; Monnard, I.; et al. Effects of protein quantity and type on diet induced thermogenesis in overweight adults: A randomized controlled trial. Clin. Nutr. 2018. [CrossRef]

48. Anderson, G.H.; Moore, S.E. Dietary proteins in the regulation of food intake and body weight in humans. J. Nutr. 2004, 134, 974S-979S. [CrossRef]

49. Veldhorst, M.A.; Nieuwenhuizen, A.G.; Hochstenbach-Waelen, A.; van Vught, A.J.; Westerterp, K.R.; Engelen, M.P.; Brummer, R.-J.M.; Deutz, N.E.; Westerterp-Plantenga, M.S. Dose-dependent satiating effect of whey relative to casein or soy. Physiol. Behav. 2009, 96, 675-682. [CrossRef] 
50. Blaak, E.E.; Antoine, J.M.; Benton, D.; Bjorck, I.; Bozzetto, L.; Brouns, F.; Diamant, M.; Dye, L.; Hulshof, T.; Holst, J.J.; et al. Impact of postprandial glycaemia on health and prevention of disease. Obes. Rev. 2012, 13, 923-984. [CrossRef]

51. Ratliff, J.; Leite, J.O.; de Ogburn, R.; Puglisi, M.J.; VanHeest, J.; Fernandez, M.L. Consuming eggs for breakfast influences plasma glucose and ghrelin, while reducing energy intake during the next 24 hours in adult men. Nutr. Res. 2010, 30, 96-103. [CrossRef]

52. Pelletier, X.; Thouvenot, P.; Belbraouet, S.; Chayvialle, J.A.; Hanesse, B.; Mayeux, D.; Debry, G. Effect of egg consumption in healthy volunteers: Influence of yolk, white or whole-egg on gastric emptying and on glycemic and hormonal responses. Ann. Nutr. Metab. 1996, 40, 109-115. [CrossRef] [PubMed]

53. Moghaddam, E.; Vogt, J.A.; Wolever, T.M. The effects of fat and protein on glycemic responses in nondiabetic humans vary with waist circumference, fasting plasma insulin, and dietary fiber intake. J. Nutr. 2006, 136, 2506-2511. [CrossRef] [PubMed]

54. Karamanlis, A.; Chaikomin, R.; Doran, S.; Bellon, M.; Bartholomeusz, F.D.; Wishart, J.M.; Jones, K.L.; Horowitz, M.; Rayner, C.K. Effects of protein on glycemic and incretin responses and gastric emptying after oral glucose in healthy subjects. Am. J. Clin. Nutr. 2007, 86, 1364-1368. [CrossRef]

55. Raben, A.; Agerholm-Larsen, L.; Flint, A.; Holst, J.J.; Astrup, A. Meals with similar energy densities but rich in protein, fat, carbohydrate, or alcohol have different effects on energy expenditure and substrate metabolism but not on appetite and energy intake. Am. J. Clin. Nutr. 2003, 77, 91-100. [CrossRef] [PubMed]

56. Flatt, J.P. Dietary fat, carbohydrate balance, and weight maintenance. Ann. N. Y. Acad. Sci. 1993, 683, $122-140$. [CrossRef] [PubMed]

57. Diaz-Toledo, C.; Kurilich, A.C.; Re, R.; Wickham, M.S.; Chambers, L.C. Satiety Impact of Different Potato Products Compared to Pasta Control. J. Am. Coll. Nutr 2016, 35, 537-543. [CrossRef] [PubMed]

58. Lee, J.J.; Brett, N.R.; Wong, V.C.H.; Totosy de Zepetnek, J.O.; Fiocco, A.J.; Bellissimo, N. Effects of Potatoes and Other Carbohydrate-Containing Foods on Cognitive Performance, Glycemic Response, and Satiety in Children. Appl. Physiol. Nutr. Metab. 2019. [CrossRef]

59. Lee, J.J.; Brett, N.R.; Chang, J.T.; de Zepetnek, J.O.T.; Bellissimo, N. Effects of White Potatoes Consumed With Eggs on Satiety, Food Intake, and Glycemic Response in Children and Adolescents. J. Am. Coll. Nutr. 2020, 39, 147-154. [CrossRef]

60. Batterham, R.L.; Heffron, H.; Kapoor, S.; Chivers, J.E.; Chandarana, K.; Herzog, H.; Le Roux, C.W.; Thomas, E.L.; Bell, J.D.; Withers, D.J. Critical role for peptide $\mathrm{YY}$ in protein-mediated satiation and body-weight regulation. Cell Metab. 2006, 4, 223-233. [CrossRef]

61. Mansour, A.; Hosseini, S.; Larijani, B.; Pajouhi, M.; Mohajeri-Tehrani, M.R. Nutrients related to GLP1 secretory responses. Nutrition 2013, 29, 813-820. [CrossRef]

62. Wren, A.M.; Bloom, S.R. Gut hormones and appetite control. Gastroenterology 2007, 132, 2116-2130. [CrossRef] [PubMed]

63. Belza, A.; Ritz, C.; Sorensen, M.Q.; Holst, J.J.; Rehfeld, J.F.; Astrup, A. Contribution of gastroenteropancreatic appetite hormones to protein-induced satiety. Am. J. Clin. Nutr. 2013, 97, 980-989. [CrossRef] [PubMed]

64. Hall, W.L.; Millward, D.J.; Long, S.J.; Morgan, L.M. Casein and whey exert different effects on plasma amino acid profiles, gastrointestinal hormone secretion and appetite. Br. J. Nutr. 2003, 89, 239-248. [CrossRef] [PubMed]

(C) 2020 by the authors. Licensee MDPI, Basel, Switzerland. This article is an open access article distributed under the terms and conditions of the Creative Commons Attribution (CC BY) license (http://creativecommons.org/licenses/by/4.0/). 